\title{
Evaluation of brush cytology (cytospin technique) and cultural results in the diagnosis of keratoconjunctivitis in a goat herd
}

\author{
Latife ÇAKIR ${ }^{1}$, Kadir Semih GÜMÜŞSOY ${ }^{2}$, Osman KUTSAL $^{3}$, Arda Selin TUNÇ ${ }^{3}$
}

\author{
Erciyes University, Faculty of Veterinary Medicine, ${ }^{1}$ Department of Pathology; ${ }^{2}$ Department of Microbiology, Kayseri; ${ }^{3}$ Ankara \\ University, Faculty of Veterinary Medicine, Department of Pathology, Ankara, Turkey.
}

\begin{abstract}
Summary: In this study, cytological examination of smears prepared with cytospin and bacteriological isolation from the samples taken with cytobrush from corneal surface of goats with keratoconjunctivitis were evaluated. An outbreak of infectious keratoconjunctivitis, which is particularly affecting kids, was determined in a herd of Saanen goats consisting of 200 animals (120 kids and 80 goats) that located in Bursa province between 2011 and 2012. One hundred and twenty kids were affected severely in this occurrence whereas approximately $10 \%$ of the mothers were affected. In clinical examinations, lacrimation and mucopurulent ocular discharge were observed in the kids. In the advanced stages of the illness, the most remarkable lesion was severe corneal edema, which is characterized by opacity and vascularizaton. Although the clinical signs started to appear solely in one eye, both eyes of all the kids were, generally, become affected whereas the mothers had unilateral ocular lesions. The mortality rate in kids reached up to $20 \%$ even though they received treatment. All of the infected mothers recovered after treatment. Ocular brush samples were randomly taken from 30 kids for cytological and microbiological examinations.

Conjunctival brush samples were examined with cytospin technique to determine whether cellular features can be utilized for cytodiagnosis. The epithelial cells collected with cytobrush were deposited onto poly-L-lysine coated slide glasses by cytocentrifuge. Slides were stained with hematoxylin and eosin (HE). All of the brush samples were cultivated at $37^{\circ} \mathrm{C}$ under aerobic conditions for microbiological investigations. The suspicious colonies were selected and subcultured for phenotypical tests. The susceptibility of isolates to the antibiotics was determined via disc diffusion method. In cytological examinations, the commonly encountered cell types in eyes with keratoconjunctivitis were neutrophils with or without bacteria located intracellularly as well as eosinophils, lymphocytes and macrophages. Extracellular bacterial clusters were also observed in some cases. Brush cytology samples taken from eyes with corneal ulcers showed significant reactive cellular changes. The most common bacteria isolated and identified were Staphylococcus aureus, Pseudomonas aeruginosa and Escherichia coli with the rates of $61.11,50$ and $47.22 \%$ respectively. All isolated strains had different susceptibility to various antibiotics. Seventy of 120 treated kids recovered within a week but the disease recurred in some of them $(n=40)$. As a result, microbial culture and cytospin preparation of ocular surface samples can contribute for identification of keratoconjunctivitis. This is the first report with regard to the occurrence of keratoconjunctivitis in Saanen goats. Moreover, this study is of importance because cytospin technique can be used to aid in the rapid diagnosis and follow up surveillance of the ocular diseases.
\end{abstract}

Key words: Brush cytology, cytospin technique, goat, keratoconjunctivitis.

\section{Bir keçi sürüsünde keratokonjunktivitisin teşhisinde fırça sitolojisi (sitospin teknik) ve kültür sonuçlarının değerlendirilmesi}

Özet: Bu çalışmada, keratokonjunktivitisli keçilerin korneal yüzeylerinden firça ile alınan örneklerin bakteriyolojik izolasyonu ve sitospinle hazırlanmış yaymalarının sitolojik incelenmesi değerlendirildi. 2011-2012 yılları arasında Bursa'da bulunan 200 başlık (120 oğlak ve 80 keçi) bir Saanen keçi sürüsünde, özellikle oğlakları etkileyen, keçilerin bulaşıcı keratokonjunktivitisi saptandı. Bu vakada 120 oğlak şiddetli olarak etkilenirken annelerin \%10' u etkilendi. Oğlaklarda klinik olarak lakrimasyon, mukopurulent oküler akıntı saptandı. Hastalığın ilerlemiş aşamalarında opaklaşma ve vaskülarizasyonla karakterize şiddetli korneal ödem belirlendi. Tüm oğlaklarda klinik bulgular bir gözde görülmeye başlayıp her iki gözü de etkiledi. Analarda ise göz lezyonları tek taraflıydı. Tedavi edilmiş olmalarına rağmen oğlaklarda mortalite oranı \%20’ye ulaştı. Tedavi sonrası tüm infekte analarda iyileşme gözlendi. Sitolojik ve mikrobiyolojik incelme için rastgele 30 oğlaktan oküler firça örnekleri alındı. Fırça ile toplanan epitel hücreleri sitosantrifüj ile poli-L-lisin kaplı lamlara alınmıştır. Lamlar, Hematoxylin-eosin (HE) boyama tekniği ile boyanarak incelenmiştir. Tüm firça örnekleri, $37^{\circ} \mathrm{C}^{\prime}$ de aerobik şartlar altında mikrobiyolojik incelemeler için kültüre edilmiştir. Şüpheli koloniler seçilmiş ve fenotipik testler için pasajlanmıştır. İzolatlarının antibiyotik duyarlılıkları disk difüzyon yöntemi kullanılarak yapılmıştır. Sitolojik incelemelerde, aktif keratokonjuktivitisli gözlerde yaygın olarak, sitoplazmalarında bakteri bulunan ya da bulunmayan

\footnotetext{
* This paper was presented as an oral presentation in 37th European Congress of Cytology, 30 September-3 October 2012, Dubrovnik-Cavtat, Croatia.
} 
polimorfonüklear nötrofil lökositler ile eozinofil lökositler, lenfosit ve makrofajlar saptandı. Ayrıca bazı örneklerde ekstrasellüler bakteri kümeleri görüldü. Kornea ülserli gözlerden alınan firça örneklerinde önemli reaktif hücresel değişiklikler mevcuttu. Alınan örneklerin mikrobiyolojik incelemesi sonucunda sirasıyla \%61,11, \%50 ve \%47,22 oranında Staphylococcus aureus, Pseudomonas aeruginosa ve Escherichia coli izole ve identifiye edildi. İzole edilen suşlar çeşitli antibiyotiklere karşı farklı duyarlılıklar gösterdi. Tedavi edilen 70 oğlağın bir hafta içinde iyileştiği ancak bu hayvanların bazılarında $(n=40)$ nüks olduğu görüldü. Sonuç olarak, oküler yüzey örneklerinin mikrobiyal kültürü ve sitosantrifüj ile hazırlanan preparatların sitolojik yönden değerlendirilmesi keratokonjunktivitisin tanısına katkı sağlayabilir. Bu çalışma, Saanen keçilerinde keratokonjunktivitis olgusunu sitospin tekniği ile saptayan ilk çalışmadır. Ayrıca, sitospin tekniğinin oküler yüzey hastalıklarının teşhisi ve takibinde kullanılabilirliğini göstermesi yönünden de bu çalışma önem taşımaktadır.

Anahtar sözcükler: Fırça sitolojisi, keçi, keratokonjunktivitis, sitospin teknik.

\section{Introduction}

Infectious keratoconjunctivitis is recognized as a worldwide contagious disease affecting the eyes of domestic and wild sheep and goats (18). It is characterized by localized inflammation of the conjunctiva and cornea. Outbreaks frequently occur when new goats are introduced to the herd when they are transported or relocated. Infection spreads easily from one eye to the other and from animal to animal $(6,8)$. Though most common in the summer and in young animals, it may occur at any time of the year and in sheep and goats of any age. It occurs in all sheep and goatraising areas of the world, though the primary causative organisms may vary (14). Identification of the causative microorganisms is the mainstay of the treatment of ocular surface infections (26). However, several bacteria have been isolated from healthy and infected goats' eyes. The absence of significant inflammation is helpful in these cases (27). Cytological examination is a valuable diagnostic tool in infective and degenerative ocular surface disorders (36). A cytospin preparation is a concentration of cells taken directly from specimens or from scraped cell cultures (28). Although there are a great number of studies related to the microbial isolation of the bacteria in infectious keratoconjunctivis in goats $(19,23,24,31,32)$, there is no previous study related to cytopathologic assessment of the goat's keratoconjunctivitis via brush cytology with cytospin technique. There are few reports concerning Gram stained smears prepared with samples taken by scraping, swab or brush of the conjunctiva in goats $(3,8)$. In humans, the cytobrush techniques is the method of choice for ocular $(13,30,34,36)$ and cervical cytology $(2,21)$. Human cytology brush can be modified for veterinary application (22). Gynecological cytobrush for collection of conjunctival specimens have been described in veterinary practice $(5,9,22)$. To the authors' knowledge, this is the first case concerning infectious keratoconjunctivitis in a herd of Saanen goats reported in Türkiye. In this study, the assessment of utilization of brush cytology with cytospin preparation in the diagnosis of caprine keratoconjunctivitis, and the correlation between the results of cytospin centrifuge and the microbiological examinations in goats with keratoconjunctivitis were evaluated.

\section{Materials and Methods}

Animals and Clinical History: The outbreak had been occurred in a herd consisting of 200 Saanen goats (120 kids and 80 mothers) in Koşuboğazı village, Mustafa Kemal Paşa county of Bursa. During the outbreak, all of the kids and approximately $10 \%$ of the mothers were affected with varying severity. The ocular specimens were collected from 30 kids aged 3.5 to 4 months. Animals were used with the permission of the Board of Ethics in Animal Experiments of Ankara University.

It was reported that outbreak occurred when a new herd of goats were brought into the farm, and the infection was seen especially in the last two years in summer months. The disease was developed within 1-2 weeks following the birth of the kids in April. The disease seen especially in the kids $(n=120)$ but rarely seen in mothers $(\mathrm{n}=8)$. The disease initially commenced in the herd as a sporadical disease, later it spread rapidly. The disease started primarily with conjunctivitis in the newborn kids with a little rheum in eyes, within a few days (3-5 days) and eyes became irritated and sometimes closed. Kids had bilateral ocular lesions whereas mothers had unilateral. Eyes of the animals had been washed with cold soapy water for treatment purpose, and later antiseptic eye drops have been applied. The mothers recover after a short time of the treatment. However, no complete recovery has been observed in kids after treatment. Then the kids were treated with antibacterial drugs, [primamycin (oxytetracycline), unofen (tilmicosin) and enrolen (enrofloxacin)] via parenteral route. In addition, eyes were washed with a mixture of penicillin with a $0.9 \% \mathrm{NaCl}$ solution, which was more effective than the previous treatment. Ratio to respond to treatment of the treated animals reached up to $70-80 \%$, but infection in these animals was seen again. Most of the kids whose eyes were closed died because of inability to reach the food and water. The mortality rate reached up to $20 \%$. The disease spread quickly in the kid population. A significant decrease in the infection rate was observed 
following the treatment but it has recurred after 15-20 days.

Clinical signs: All the affected kids showed depression, serous or muco-purulent ocular discharge. In early stages, the disease presented unilateral or bilateral conjunctivitis with hyperaemia of the vessels. In general, both eyes were affected, although severity of symptoms differed between two eyes. The macroscopic changes in the eyes were characteristic. In advanced stage, a mild corneal opacity with the accompanying ulcer and conjunctivitis were seen. In more advanced stages, the process extended over the whole cornea, causing a bluegreyish turbidity and corneal ulceration (Figure 1) and later on herniation in the centre of the eyes has been encountered. This kind of cases possed irreversible changes from the point of view of vision.
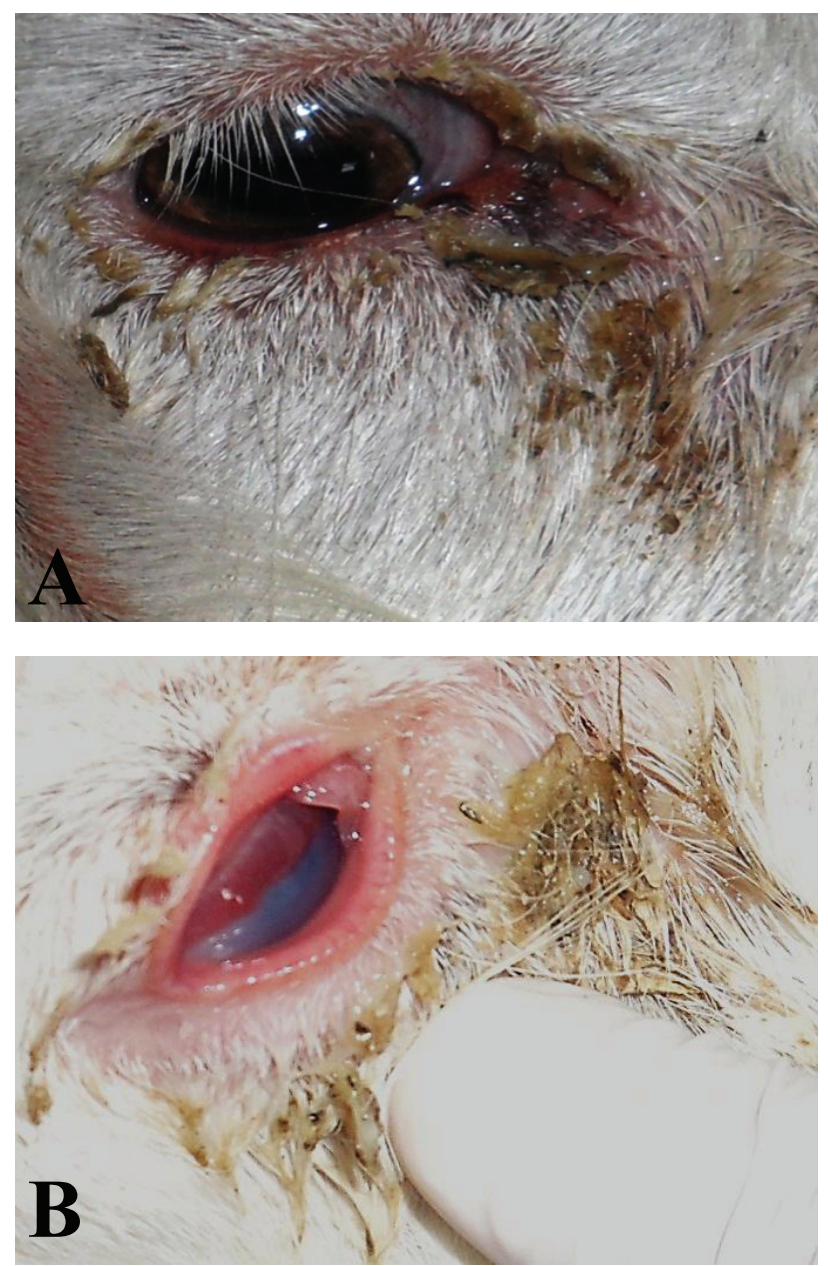

Figure 1. A) Keratoconjunctivitis in the eyes of the kids. Plumped scleral blood vessels, and muco-purulent ocular effusion. B) Severe corneal ulcer characterized by a corneal cellular infiltrate (blue-grayish opacity) and perilesional corneal edema and vascularization.

Şekil 1. A) Keratokonjunktivitisli oğlak gözü. Skleral kan damarlarında dolgunluk, mukopurulent oküler efüzyon. B) Korneal hücresel infiltrasyon (mavi-grimsi bulanıklık), lezyon etrafinda korneal ödem ve vaskülarizasyonla karakterize korneal ülser.

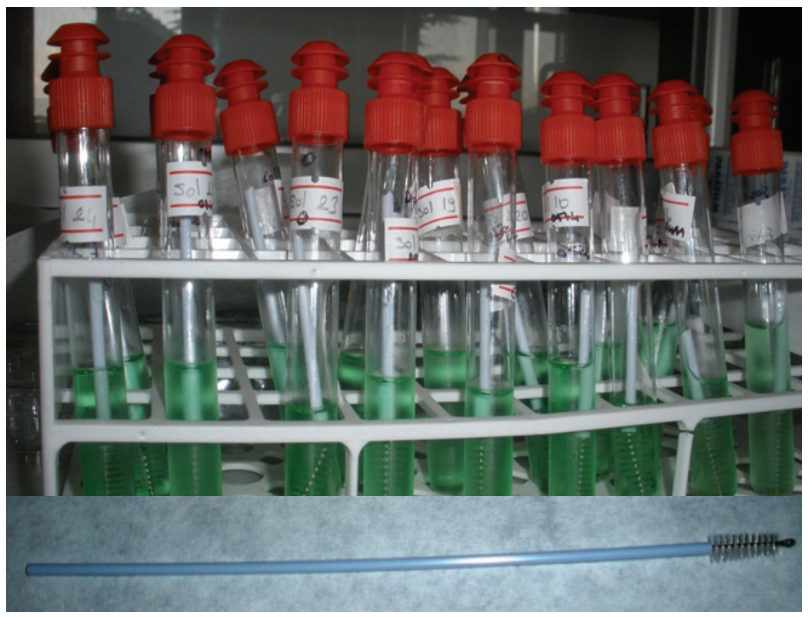

Figure 2. Top. Cytobrush immersed in Cytospin collection fluid. Bottom. Cytobrush for ocular samples used for bacteriological and cytological examination.

Şekil 2. Üst. Sitospin hücre koruyucu solüsyonuna daldırılmış firça. Alt. Oküler yüzeyden bakteriyolojik ve sitolojik örnek almak için kullanılan firça.

Cytospin Technique: Conjunctival brush samples were obtained from one eye of each of the 30 kids picked at random. A special brush (Cytobrush, Gynobrush Plus, Germany) that is used in cervical cytology in human (7) was used in order to collect conjunctival cells efficiently. After topical application of anaesthetic to the temporal bulbar and forniceal area, the samples were obtained from the conjunctiva by rotating the cytobrush gently under slit lamp observation. Brushes were taken into fixative solution (Cytospin collection fluid, Thermo Shandon 6768001, USA), and cytocentrifuged at 1500 rpm for 15 minutes (Figure 2). Epithelial cells collected by the brush cytology technique were deposited onto poly L-lysine coated slide glasses by cytocentrifugation (Cytospin; Thermo Shandon Southern Ltd, Cheshire, England). Wet cytocentrifuged slides were drawn out, dried and stained with Hematoxylin-eosin (HE). The slides were mounted with mounting medium (Merck). All slides were photographed with a digital camera (Olympus DP71) and digital programmers (DP Controller and the DP Manager) fitted to a microscope (BX-51, Olympus) (minimum of 4 fields per slide, using x10, x40, and x100 objectives).

Microbiological Examinations: Ocular specimens were collected with a pre-moistened brush with sterile saline and applied to surfaces of conjunctiva and cornea. Samples were taken into tubes containing Cary-Blair transport media (Lab M, UK) and immediately submitted to microbiology laboratory. They were inoculated onto blood agar (Merck, Germany) and Mac Conkey agar (Merck, Germany) and incubated at $37{ }^{\circ} \mathrm{C}$ for $24-48$ hours. The suspicious colonies were selected and subcultured for phenotypical tests. The antibiotic susceptibility testing was performed using disc diffusion method (4). In antibiotic susceptibility test, a total of 14 
different antibiotic discs soaked with amoxicillin $(25 \mu \mathrm{g})$, amoxicillin-clavulanic acid $(30 \mu \mathrm{g})$, cefotaxime $(30 \mu \mathrm{g})$, ciprofloxacine $(30 \mu \mathrm{g})$, enrofloxacin $(5 \mu \mathrm{g})$, gentamycin $(10 \mu \mathrm{g})$, imipenem $(10 \mu \mathrm{g})$, penicillin $(10 \mu \mathrm{g})$, neomycin (30 $\mu \mathrm{g})$, norfloxacin $(30 \mu \mathrm{g})$, oxytetracyclin $(30 \mu \mathrm{g})$, tetracyclin $(30 \mu \mathrm{g})$ and tobramycin $(10 \mu \mathrm{g})$ were used.

\section{Results}

Cytological findings: The morphological appearance of epithelial cells was evaluated. The cytological samples exhibited abundant cellularity with very homogeneous cell size. In cytological examination of ocular surface, rounded small cells, mucus secreting goblet cells and columnar epithelial cells of normal conjunctiva with noncornified squamous epithelium of cornea were common in some samples. These cells with eosinophilic stained cytoplasm had similar shape and sizes. The type of cells commonly encountered from eye with active conjunctivitis and keratitis were polymorphonuclear neutrophils, lymphocytes and macrophages. Mucus and keratin were seen in most of the cases. Neutrophils, with or without bacteria located intracellularly or extracellular bacterial cluster were abundant. Significant dysplastic changes in epithelial cells were present in a few samples with corneal ulcers. The dysplastic changes were consisted of enlarged hyperchromatic nuclei, bi- and multinucleated cells with increased nuclear/cytoplasmic ratio and irregular nuclear contour. In the squamous metaplasia of conjunctiva, the cells with abundant cytoplasm, reduced nuclear/cytoplasmic ratio and pyknotic nuclei were observed (Figure 3).

Bacteriological Findings: Staphylococcus aureus was the most frequently occurring Gram-positive strain
(61,11\%), and Pseudomonas aeruginosa was the predominant Gram-negative strain (50\%), Escherichia coli $(47.22 \%)$ were commonly isolated pathogens from eyes of goats at rates.The results of antibiotic susceptibility testing are presented as Table1.

\section{Discussion and Conclusion}

The cytology is a minimally invasive diagnostic tool that continues to expand in veterinary medicine (11, 15). The cytology is involved in the conditions such as chronic or severe ocular surface inflammation and/or abscesses, ocular surface diseases that do not respond to therapy, progressive or deep melting corneal ulcers and proliferative masses of the cornea, conjunctiva and nictitating membrane. Samples for cytological examinations can be collected from ocular surface by scraping (swabs or cytobrush) and impression smears (7, $9,10,17,20,35)$. It has been reported that the nylonbristled cytobrush is used to obtain the best diagnostic sample (36). The cytobrush technique has the advantages such as increased total number of cells, acquisition of cells from deeper layers with less intervention, high quality cell morphology, and reduced cell overlapping $(11,36)$. This technique also provides the opportunity for simultaneous studies of the samples taken from very different areas of the ocular surface. The cytobrush is commonly used as a tool for obtaining cervical samples as well as ocular samples in human $(2,30,36)$. However, it has been reported in limited studies in veterinary pathology $(5,9,18,22,26)$ that the same type cytology brushes are used successfully for ocular cytology in dogs and cats.

Table 1. Antibiotic susceptibility of the bacteria isolates from kids eye with keratoconjunctivitis.

Tablo 1. Keratokonjuktivitisli oğlaklardan izole edilen bakterilerin antibiyotiklere duyarlılıkları.

\begin{tabular}{|c|c|c|c|c|c|c|}
\hline \multirow{2}{*}{$\begin{array}{l}\text { Bacteria } \\
\text { Antibiotics }\end{array}$} & \multicolumn{2}{|c|}{ Pseudomonas aeruginosa } & \multicolumn{2}{|c|}{ Staphylococcus aureus } & \multicolumn{2}{|c|}{ Escherichia coli } \\
\hline & $\begin{array}{c}\text { Zone of inhibition } \\
(\mathrm{mm})\end{array}$ & Sensivity & $\begin{array}{c}\text { Zone of } \\
\text { inhibition }(\mathrm{mm})\end{array}$ & Sensivity & $\begin{array}{c}\text { Zone of } \\
\text { inhibition }(\mathrm{mm})\end{array}$ & Sensivity \\
\hline Amoxycillin & 25 & $\mathrm{~S}$ & 27 & $\mathrm{~S}$ & 17 & I \\
\hline Amoxycillin-Clavulanic acid & 26 & $\mathrm{~S}$ & 28 & $\mathrm{~S}$ & 17 & I \\
\hline Cefotaxime & 18 & I & 17 & I & 16 & I \\
\hline Cefuroxime sodium & 24 & $\mathrm{~S}$ & 25 & $\mathrm{~S}$ & 17 & I \\
\hline Ciprofloxacine & 16 & I & 21 & $\mathrm{~S}$ & 20 & I \\
\hline Enrofloxacin & 27 & $\mathrm{~S}$ & 24 & $\mathrm{~S}$ & 16 & I \\
\hline Gentamycin & 14 & I & 16 & S & 14 & I \\
\hline Imipenem & 14 & I & 15 & I & 14 & I \\
\hline Penicillin & 10 & $\mathrm{R}$ & 25 & I & 0 & $\mathrm{R}$ \\
\hline Neomycin & 15 & I & 7 & $\mathrm{R}$ & 0 & $\mathrm{R}$ \\
\hline Norfloxacin & 16 & I & 14 & I & 13 & I \\
\hline Oxytetracyclin & 15 & I & 8 & $\mathrm{R}$ & 18 & I \\
\hline Tetracycline & 17 & I & 16 & I & 18 & I \\
\hline Tobramycine & 14 & I & 13 & I & 10 & $\mathrm{R}$ \\
\hline
\end{tabular}

Sensitivity : R:Resistant, I: Intermediate, S: Susceptible. 

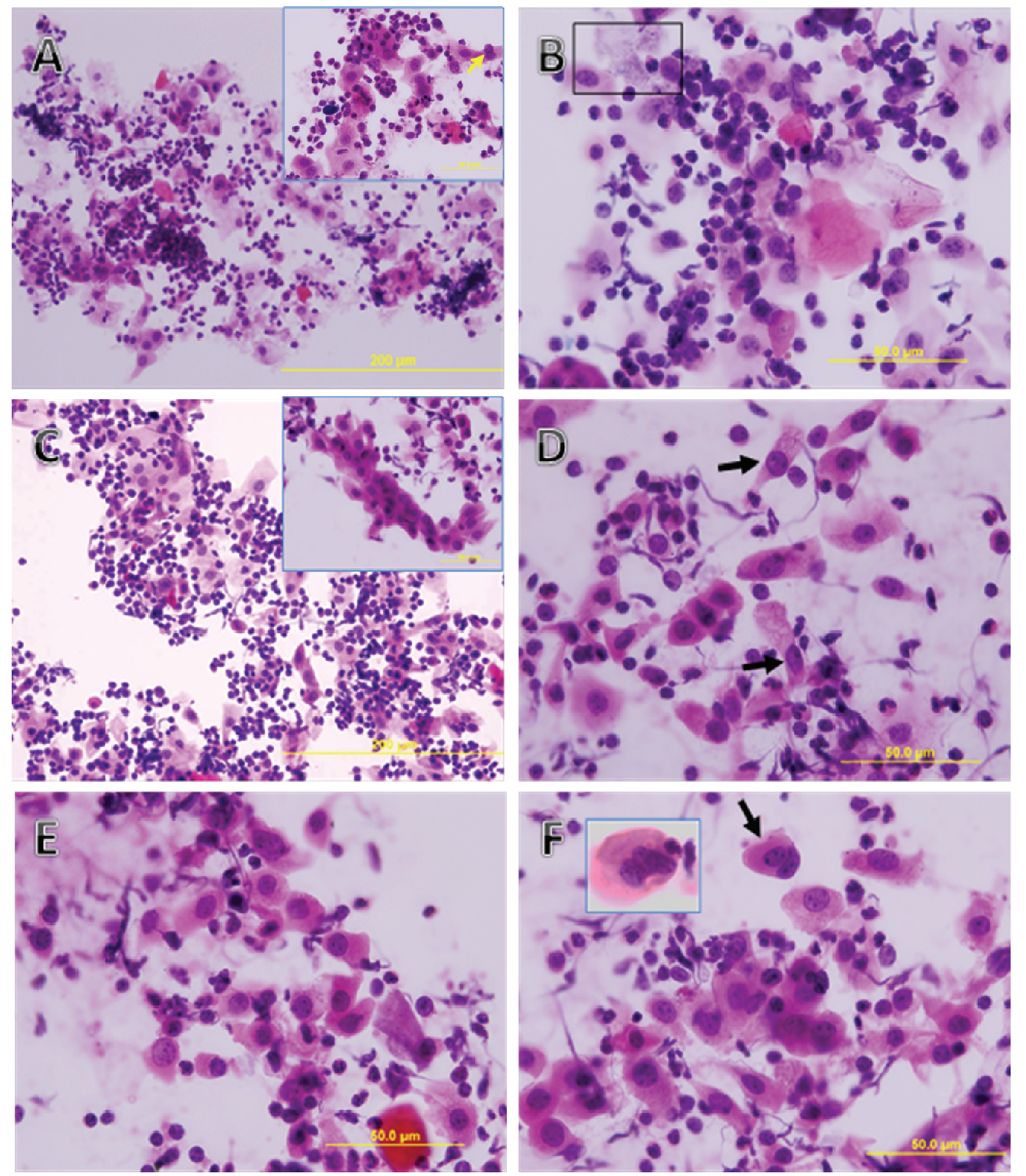

Figure 3. Cytospin preparation of ocular surfaces with keratoconjunctivitis and corneal ulcer (HE). A) Intensive neutrophil leucocytes with squamous epithelial cells background showing keratoconjunctivitis. Inset shows higher magnification. B) The presence of degenerative neutrophils and clump of bacteria (framed area). C) Mononuclear (macrophages, lymphocytes, and plasmocytes) and conjunctival epithelial cells seen in samples taken with brush. Inset shows epithelial cells arranged in cell group. D) The plump and oval Goblet cells (arrows) with light cytoplasm among the dysplastic cells. E) Dysplastic cells that have well defined cytoplasm, increased nucleocytoplasmic ratio, hyperchromasia and nuclear pleomorphism. F) Binucleated (arrow) and trinucleated conjunctival epithelial cell (inset).

Şekil 3. Oküler yüzeyin sitospin tekniğiyle hazırlanan keratokonjunktivitis ve kornea ülserini gösteren preparatlar A) Keratokonjunktivitisi gösteren yoğun nötrofil lökositler ile skuamöz epitel hücreler. Ekli resim daha büyük büyütmeyi göstermektedir. Çift çekirdekli hücreler (sarı ok). (B) Dejeneratif nötrofil lökositler ve bakteri kümeleri (ekli alan). C) Konjunktival epitel hücrelerini de içeren çok sayıda mononüklear hücreleri (makrofaj, lenfosit, plazma hücresi) gösteren firça örneği. Ekli resim düzenli hücre gruplarını göstermektedir. D) Displazik hücreler arasında dolgun ve oval şekilli, açık renk sitoplazmalı goblet hücreleri (oklar). E) Hiperkromazi ve nükleer pleomorfizm gösteren, sitoplazmaları belirgin ve nükleositoplazma oranı artmış olan displazik hücreler. F) Çift çekirdekli (ok) ve üç çekirdekli (ekli resim) konjunktival epitel hücreleri. 
Wills et al. (35) who clinically assessed the conjunctive cell morphology in normal dogs and cats have indicated that cytobrush is an effective technique in the determination of the conjunctival changes. Hillström et al. (16) have also used brush cytology in the diagnosis of feline conjunctivitis, and indicated that transfer of cells from the brush to the slide must be gentle to avoid fragmentation of the cells, but enough pressure must be used to ensure adequate transfer of cells to the glass slide.

The cytospin technique has been used widely for many years for processing urine, respiratory specimens, and body fluids in human $(2,29)$. The cytospin monolayer technique allows the diagnosis of intraocular lymphoma (12). This quick, inexpensive and non-invasive method may have a role in diagnosis, screening and surveillance of patients. The primary publications regarding brush cytology, and very limited studies on cytological sample collection techniques for ocular diseases were concerned mostly with the conventional direct smear method $(3,8$, 10). To the authors' knowledge, no previous study has reported the diagnosis of keratoconjunctivis by cytospin technique with cytobrush in goats' ocular cytology. Therefore, in this study, the preparations of ocular samples collected by cytobrush and prepared by cytospin centrifuge were examined and the effectiveness of cytospin technique in the diagnosis of keratoconjunctivis seen in goats was evaluated.

Conjunctival flora of goats consists of many resident microorganisms (25). Severel bacteria such as Staphylococcus aureus, Pasteurella haemolytica, Moraxella bovis, Mycoplasma spp. were isolated from the eyes of healthy goats (26). Given a chance any organism can cause opportunistic infections in humans (29) and very occasionally in goats $(14,26)$. The microorganisms that are commonly isolated in the domestic and wild caprinae with keratoconjunctivitis are Mycoplasma spp., Chlamydia psittaci, aerobic bacteria (Neisseria ovis, Staphylococcus aureus, Streptococcus spp., Moraxella spp, Escherichia coli, Pseudomonas spp, Arcanobacterium pyogenes, Listeria monocytogenes) (1, $3,6,8,14,19,25)$. Therefore, cytological examination together with the culture of the ocular specimens remains as the gold standard for differential diagnosis (29). In this study, only a few bacteria such as $S$. aureus, $P$. aeruginosa and E. coli, were isolated from kids with clinical signs of keratoconjunctivitis, and they were considered as possible aetiological agents as indicated in previous studies $(3,8,14)$.

The choice of antimicrobial therapy before obtaining antimicrobial susceptibility testing results must be based on clinical signs and cytological findings (24, 27). In the present study, S. aureus and P. aeruginosa were found to be susceptible to amoxicillin, amoxicillin clavulanic acid, cefuroxim sodium and enrofloxacin whereas $E$. coli was found to be resistant to all of the antibiotics tested in this study, which can be attributed to the resistance of the $\mathrm{E}$. coli strains to antibiotics in general.

The cytological evaluation of ocular samples is of importance for identification of keratoconjunctivitis, especially in animals receiving antimicrobial treatment. In the cytological assessments, if the predominant cell type is degenerative neutrophils, then the most common underlying causes are bacteria or fungi in the aetiology of the eye diseases $(2,15)$. In this study, squamous metaplasia may be indicative of a higher degree of epithelial damage of conjunctival epithelial cells, and presence of neutrophils and macrophages is a strong indicator of an inflammatory aetiology for this disease. The observation of neutrophils with intracellular bacteria as well as presence of the in extracellular bacterial clusters, which were in agreement with the previous reports $(9,11,15)$, showed infection, thus antibiotic therapy were based on evidence of polymorphonuclear cells along with the results of culture and susceptibility testing of the isolated strains.

Multinucleated epithelial cells have been noted in people (33) with conjunctivitis and have been reported in feline keratoconjunctivitis (16). Binucleated epithelial cells were commonly seen in the presented study as previously reported in dogs $(9)$ and human $(29,36)$ with keratoconjunctivitis. These cells may indicate reactive changes in sites of intense chronic inflammation.

The results of the present study have suggested that cytospin centrifuge together with brush cytology, which is a rapid and inexpensive technique, provides good quality sample preparations thus can be used efficiently along with the bacterial culture for monitoring of corneal damage and the early diagnosis of keratoconjunctivitis in goats.

\section{References}

1. Abbas B, Razig SA (1979): The etiology of keratoconjunctivitis occurring in goats in the Sudan. Vet Rec, 105, 348-350.

2. Atkins KA, Powers CN ( 2002): The cytopathology of infectious diseases. Adv Anat Pathol, 9, 52-64.

3. Bankemper KW, Lindley DM, Nusbaum KE, Mysinger RH (1990): Keratoconjunctivitis associated with Neisseria ovis infection in a herd of goats. J Vet Diagn Invest, 2, 76-78.

4. Bauer AW, Kirby WMM, Sherris JC, Turck M (1966): Antibiotic susceptibility testing by a standardized single disk method. Am J Clin Pathol, 36, 493-496.

5. Bauer GA, Spiess BM, Lutz H (1996): Exfoliative cytology of conjunctiva and cornea in domestic animals: a comparison of four collecting techniques. Vet Comp Ophthalmol, 6, 181-186.

6. Belloy L, Janovsky M, Vilei EM, Pilo P, Giacomettim M, Frey J (2003): Molecular epidemiology of Mycoplasma conjunctivae in caprinae: Transmission across species in natural outbreaks. Appl Environ Microbiol, 69, 19131919. 
7. Bolzan, A, Brunelli AJ, Castro M, Souza M, Souza J, Laus J (2005): Conjunctival impression cytology in dogs. Vet ophthalmol, 8, 401-405.

8. Busch TJ, Belton DR (1988): Infectious keratoconjunctivitis in goats. $\mathrm{N} Z$ Vet J, 36, 153-155.

9. Çakır L, Hizlısoy H, Abay S, Kutsal O (2011): Investigation of ocular surface cytology (brush-impression techniques) and Bacteriological Agents in dogs with Conjunctivitis and Healthy. Cytopathology, 22, 19.

10. Dagnall GJ (1994): Use of exfoliative cytology in the diagnosis of ovine keratoconjunctivitis. Vet Rec, 135, 127130.

11. Dubielzig RR, Ketring KL, McLellan GJ, Albert DM (2010): Veterinary Ocular Pathology A Comparative Review. 1st Edition. Saunders Elsevier, Oxford.

12. Finger PT, Papp C, Latkany P, Kurli M, Iacob CE (2006): Anterior chamber paracentesis cytology (cytospin technique) for the diagnosis of intraocular lymphoma. $\mathrm{Br} \mathrm{J}$ Ophthalmol, 6, 690-692.

13. Fujihara T, Takeuchi T, Saito K, Kitajima Y, Kobayashi TK, Tsubato K (1997): Evaluation of Human Conjunctival Epithelium by a Combination of Brush Cytology and Flow Cytometry: An Approach to the Quantitative Technique. Diagn Cytopathol, 17, 456-460.

14. Giacometti M, Janovsky M, Belloy L, Frey J (2002): Infectious keratoconjunctivitis of ibex, chamois and other Caprinae. Rev Sci Tech Off Int Épizoot, 21, 335-345.

15. Gilger BC (2006): Ocular cytology-your key to immediate ocular diagnosis. 871-872. In: Proceedings of the North American Veterinary Conference, NAVG Gainesville, FL, USA.

16. Hillström A, Tvedten H, Maria Källberg M, Hanås S, Lindhe A, Holst BS (2012): Evaluation of cytologic findings in feline conjunctivitis. Vet Clin Path, 41, 283-290.

17. Jégou JP, Liotet S (1993): The benefit of conjunctival scraping cytology in the biological diagnosis of conjunctivitis in the dog and cat. EJCAP, 3, 83-97.

18. Jones GE (1991): Infectious keratoconjunctivitis. 280283. In: Martin WB., Aitken ID., Editors: Diseases of sheep, Blackwell Scientific Publications.

19. König CD (1983): Keratoconjunctivitis infectiosa ovis (KIO), 'pink eye' or 'zere oogjes' (a survey). Vet Q, 5, 127130.

20. Lavach JD, Thrall MA, Benjamin MM, Severin GA (1977). Cytology of normal and inflamed conjunctivas in dogs and cats. J Am Vet Med Assoc, 170, 722-727.

21. Levine TS, Rolfe KJ, Crow J, Styles S, Perrett CW, Maclean AB, Reid WMN (2001): The use of cytospin monolayer technique in the cytological diagnosis of vulval and anal disease. Cytopathology, 12, 297-305.

22. Maggs DJ (2001): Laboratory investigation of ophthalmic disease. 24-29. In: Petersen-Jones SM, Crispin S (Eds), BSAVA Manual of Small Animal Ophthalmology. Second Edition. British Small Animal Veterinary Association, England.

23. Marco I, Mentaberre G, Ballesteros C, Bischof DF, Lavín S, Vilei EM (2009): First Report of Mycoplasma conjunctivae from Wild Caprinae with Infectious Keratoconjunctivitis in the Pyrenees (NE Spain). J Wildlife Dis, 45, 238-241.

24. Massa KL, Murphy CJ, Hartmann FA, Miller PE, Korsower CS, Young KM (1999): Usefulness of aerobic microbial culture and cytological evaluation of corneal specimens in the diagnosis of infectious ulcerative keratitis in animals. J Am Vet Med Assoc, 215,1671-1674.

25. Mayer D, Nicolet J, Giacometti M, Schmitt M, Wahli T, Meier W (1996): Isolation of Mycoplasma conjunctivae from conjunctival swabs of Alpine ibex (Capra ibex ibex) affected with infectious keratoconjunctivitis. J Vet Med Ser B, 43, 155-161.

26. Mushi EZ, Binta MG, Chabo RG, Dintwe K (2007): Conjunctival Flora of Fifty Healthy Goats in Sebele Farm, Gaborone, Botswana. J Anim Vet Adv, 6, 1388-1389.

27. Prado MR, Rocha MFG, Brito ÉHS, Girão MD, Monterio AJ, Teixeira MFS, Sidrim JC (2005): Survey of bacterial microorganisms in the conjunctival sac of clinically normal dogs and dogs with ulcerative keratitis in Fortaleza, Ceará, Brazil. Vet Ophthalmol, 8, 33-37.

28. Shanholtzer CJ, Schaper PJ, Peterson LR (1982): Concentrated gram stain smears prepared with a cytospin centrifuge. J Clin Microbiol, 16, 1052-1056.

29. Sharma S (2012): Diagnosis of infectious diseases of the eye. Eye, 26,177-84.

30. Takano Y, Fukagawa K, Dogru M, Asano-Kato N, Tsubota K, and Fujishima H (2004): Inflammatory cells in brush cytology samples correlate with the severity of corneal lesions in atopic keratoconjunctivitis. $\mathrm{Br} \mathrm{J}$ Ophthalmol, 88, 1504-1505.

31. Ter Laak EA, Schreuder BE, Smith-Buys CM (1998): The occurance of Mycoplasma conjunctivae in the Netherlands and its association with infectious keratoconjunctivitis in sheep and goats. Vet Quart, 10, 73-83.

32. Tschopp R, Frey J, Zimmermann L, Giacometti M (2005): Outbreaks of infectious keratoconjunctivitis in alpine chamois and ibex in Switzerland between 2001 and 2003. Vet Rec, 157,13-18.

33. Uchida Y (1990): Viral diseases of the outer eye-rapid diagnosis by immunohistochemistry. Nippon Ganka Gakkai Zasshi, 94, 889-902.

34. Wakamatsu TH, Okada N, Kojima T, Matsumoto Y, Ibrahim, OMA, Adan ES, Fukagawa K, Katakami C, Tsubota K, Shimazaki J, Fujishima H (2009): Evaluation of conjunctival inflammatory status by confocal scanning laser microscopy and conjunctival brush cytology in patients with atopic keratoconjunctivitis (AKC). Mol Vis, 15, 1611-1619.

35. Willis M, Bounous DI, Hirsh S, Kaswan R, Stiles J, Martin C, Rakich P, Roberts W (1997): Conjunctival brush cytology: evaluation of a new cytological collection technique in dogs and cats with a comparison to conjunctival scraping. Vet Comp Ophthalmol, 7, 74-81.

36. Yağmur M, Ersöz C, Ersöz TR, Varinli S (1997): Brush technique in ocular surface cytology. Diagn Cytopathol, 17, 88-91.

Geliş tarihi: 02.08.2013 / Kabul tarihi: 09.10.2013
Address for correspondance
Latife ÇAKIR, DVM, PhD
Associate Professor
Department of Pathology
Faculty of Veterinary Medicine
University of Erciyes, 38039, Kayseri, Turkey
e-mail:lcakir@erciyes.edu.tr 